\title{
THE ANALYSIS OF MEANINGS AND FORMS IN THE A.T. MAHMUD'S SONG LYRICS
}

\author{
$\triangle$ Prastiana Ekaningrum \\ ${ }^{凶}$ Teacher of Junior High School 7 Magelang, Central Java Indonesia \\ E-mail: preshtea.mail@gmail.com
}

Suharto

Music Department, Universitas Negeri Semarang

Received: April 22, 2015. Revised: May 5, 2015. Accepted: June 13, 2015

\begin{abstract}
The purpose of this study is to describe the analysis of meanings in the A.T. Mahmud's song lyrics. This research used the approach of music compositions and the language approach in semantics to find out the meanings of the lyrics. This research used content analysis techniques. The analysis includes two aspects; they are: (1) the analysis of the meanings of the song lyrics based on the language aspects; and (2) the analysis based on the aspects of the music compositions. The songs to be analyzed are Bintang Kejora, Pelangi, and Cicak. The lyrics of these songs indicate that in the process of creation, Mahmud focused on the beauty of the language, such as the diction, figure of speech, rhyme, and repetition. The songs use children words that correspond to the child's development, so that children understand and memorize easily. The songs created by A.T. Mahmud are mostly about daily life; the suitable themes for children's characteristics and world. Based on the analysis in the music compositions, most of the songs form two parts and each part of the song consists of two phrases or sentences.
\end{abstract}

Keywords: analysis of meaning; figure of speech; form analysis; song lyrics; music composition

How to Cite: Ekaningrum, P. (2015). The Analyses of Meanings and Forms in The A.T. Mahmud's Song Lyrics. Harmonia: Journal of Arts Research And Education, 15(1), 9-15. doi:http:/ / dx.doi.org/10.15294/harmonia.v15i1.3691

\section{INTRODUCTION}

Viewed from the characteristics of melody and lyrics, there are many kinds of songs that thrive in the community, one of which is a children's song. In the typography view of text or lyric arrangements, children's songs are actually a kind of modern poem as a result of an adult's creation. The lyrics are written in short and simple words, but easy to understand so the songs will be meaningful for children.

The listeners of the songs not only enjoy the tones of the music, but also the lyrics. The lyrics represent the writer's mind and help the listeners to understand what is in the writer's mind. In addition, the listeners sometimes prefer a song for the lyrics. Therefore, the lyrics can also take a role in determining whether a song will be favored or not.

Music for children viewed both vocal and instrumental is the idea and the feeling of the children since it is something in their subjective world which is simple, and also uses simple language, but interesting to perform.

Music in the song needs lyrics. The lyrics are sometimes in the form of literature, especially a poem, even in the children's songs. However, the literature featured in the children songs' lyrics is normally as simple as the melody. According to Nurgiyantoro (2005, P. 6), children's literature is a literature that in the emotional psychological view is addressed and can be easily understood by children. It usually goes from facts and easy to imagine. 
The literature can be seen in the use of figures of speech. Types of these figures according to Tarigan (1986) can be classified into four: (1) the figures of comparison including the parables, metaphor, personification, allegory, and antithesis, (2) the figures of contradiction including the hyperbole, irony, litotes, oxymoron, paronomasia, zeugma, and paralysis, (3) the figures of conjunction including the metronome, synecdoche, allusion, euphemism, ellipsis, inversion, and grads, and (4) the figures of repetition consisting of alliteration, antanachlasys, chiasmus, and repetition. The figures of speech in the children's songs are still limited adjusted to children's psychology and their power of imagination.

The results of Wahyuni's study (2012) about the meaning of figures in song lyrics, one of which concluded that the functions of figures are to give a powerful effect, to concrete a statement, to clarify or confirm an intention, and to beautify a statement. In addition, they also serve to provoke mind power, smooth tones, hide the intention, deliver a message, refine the language, and enrich the meaning.

The melody in the children's song lyrics also have educational functions. One of those functions is to introduce the vocabulary as well as the musical experience required for the child's development. Thornbury (2002, p. 23) said that learning vocabulary is not only learning the numbers of words, but also remembering them. Therefore, any vocabulary in the lyrics for the intention to educational purpose should educate students to understand the vocabulary through the beauty of the melody as well as enrich vocabulary. The words in the song lyrics will always mean to touch the children's soul as the melody is in harmony with the lyrics. Therefore, the lyrics are not only beautiful, but also meaningful to the children's soul.

The lyrics and the melody in the music compositions can be created at the same time, or separately. However, the lyrics will usually synchronize with the meaning of melody when they are created at the same time. This is due to Suharto's statement (2004: 49) that melodies and lyrics are a unity in the song.

A song really helps students to achieve their full mental, intelligence, and creativity as they learn through repetition, i.e. the lyrics that use a figure of repetition and multisensory activities. The song can be helpful in considering the concept of the language skills from speech to listening and speaking skills (Intani, 2012).

Based on the needs and characteristics of the child, Abdullah Totong Mahmud, or commonly known as A.T. Mahmud is one of the children's song writers whose songs are still popular to this day. $\mathrm{He}$ is really concerned with the theme, meaning, and form of the music. Upon doing so, this article contains the analysis of three songs of A.T. Mahmud; they are Bintang Kejora, Pelangi, and Cicak. The analyses of these song lyrics are reviewed from the aspects of the language and the meaning of the song from the analysis of the music composition.

\section{METHOD}

This research uses the approach of musicology to analyse the music composition. In addition, the study also uses the language approach, especially its semantics, to find out the meaning of the lyrics. The songs to analyse are the children's songs of A.T. Mahmud entitled Bintang Kejora, Pelangi, and Cicak. The data of the research are the analyses of children's songs of A.T. Mahmud. The technique to collect data is library research. The data are analysed using a content analysis technique as this analysis aims to point out the meanings in the lyrics and to describe elements in the songs.

\section{RESULTS AND DISCUSSION}

This chapter will describe the analyses of meaning in the lyrics of A.T. Mahmud's songs based on the beauty of language and the music composition in the songs Bintang Kejora, Pelangi, and Cicak. 
Analysis of the Meaning of the Lyrics based on the Language Beauty Aspects

The analysis of the meaning of lyrics in A.T. Mahmud songs based on the language beauty are as follows.

\section{The song Bintang Kejora}

Here is the song notation and the lyrics of Bintang Kejora that consists of 16 sections bars.

\section{Bintang Kejora $\mathrm{F}=\mathrm{do}, 4 / 4$}

A.T. Mahmud

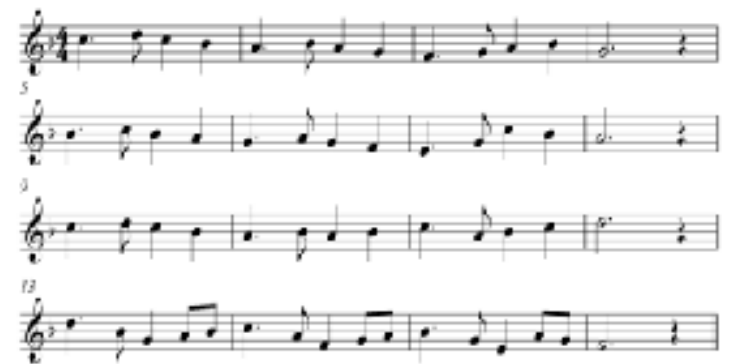

Lyrics:

Kupandang langit penuh bintang bertaburan Berkelap-kelip seumpama intan berlian

Tampak sebuah lebih terang cahayanya Itulah bintangku bintang

kejora yang indah slalu

The song lyrics explain that the theme of the song Bintang Kejora is the majesty of God expressed through the beauty of the night with full of stars. In general, this song tells a story of a child who is looking at the night sky. This explains the lyrics $k u-$ pandang langit penuh bintang bertaburan.

The lyrics berkelap-kelip seumpama intan berlian on the second verse show that the stars flicker like a diamond, which is also flickering. The lyrics use a figure of comparison, simile. The explicit comparison can be expressed using prepositions and conjunctions, such as layaknya, bagaikan, umpama, ibarat, bak, and bagai. These characteristics indicate that the lyrics are a poem that includes the figure of speech in it to embellish. The poems used in the lyrics of A.T. Mahmud songs are simple since it is intended to children.

The lyrics of the song Bintang Kejora describe that at that time the sky looked bright and there were many stars. There were small and big stars, forming a cluster of stars. There was a bright star, and it was brighter than others. This brighter star was what he's pointing to and what he considered as his own star. He wanted to be like the star due to its beauty, always be special in his family and the environment. That inspired him to be a good one.

In two early verses of the song lyrics, the final words 'bertaburan' and 'berlian' are the repetition of the sound ' $a n^{\prime}$ ', indicating that there are elements of beauty. There is a similar rhyme at the end of the sentence. The lyrics 'intan' and 'berlian' also have a similarity of the sound ' $a n^{\prime}$ ' that indicates elements of the beauty of sound which is beautiful when it is sung. The repetition of sound on both verses is as follows.

\section{Kupandang langit penuh bintang bertaburan Berkelap-kelip seumpama intan berlian}

There is a word repetition in the song Bintang Kejora. The repeated word is bintang on the lyrics of the third verse. A repetition is a repeated sound, syllable, word, or parts of sentences that are considered essential to put stressing in the context (Keraf, 1996: 127). The repetition is intended to reaffirm, as the focus or the main object of this song is bintang kejora. In addition, the lyrics are suitable for children since they are expected to be easier to memorize.

\section{The Song Pelangi}

The notation and lyrics of the song Pelangi consist of 16 sections bars as follows. 


\section{Pelangi \\ $\mathrm{F}=\mathrm{do}, 4 / 4$ \\ A.T. Mahmud Moderato}

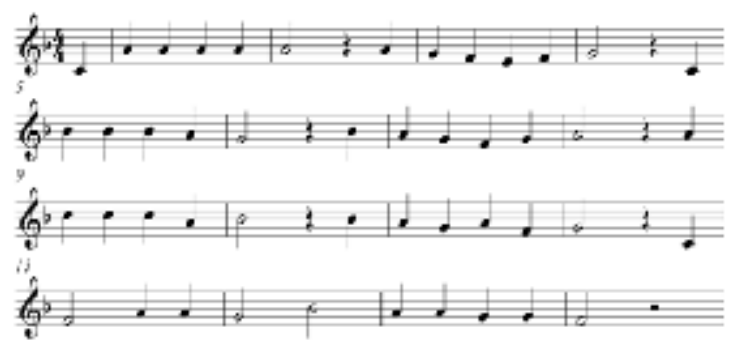

Lyrics:

Pelangi-pelangi, alangkah indahmu

Merah, kuning, hijau di langit yang biru

Pelukismu agung, siapa gerangan

Pelangi-pelangi, ciptaan Tuhan.

The theme of the song Pelangi is the majesty of God. The lyrics pelangi-pelangi alangkah indahmu show an admiration to God's creation. It is a beautiful rainbow with seven colors; they are red, orange, yellow, green, blue, indigo, and violet.

The writing of lyrics merah kuning di langit yang biru is intended to introduce colors to the children. The color diversity in a rainbow will be known and understood when children sing the song. In addition, the end of the song's lyrics also explains that the color of the sky is mostly blue.

The lyrics 'pelukismu agung, siapa gerangan' show that a rainbow is very beautiful like a painting. To inquire the creator of a rainbow, through this song, A.T. Mahmud chose beautiful phrases in the lyrics 'siapa gerangan?' instead of using the words 'siapa yang menciptakan', or something.

The next song lyrics are Pelangi-Pelangi ciptaan Tuhan indicates that a rainbow is one of the God's creations; a God who creates the universe and its contents, including the earth, sky, and the rainbow. Based on the meaning of the song lyrics, A.T. Mahmud hoped when the children sing the song, they will get to know the variety of colors through the medium of a natural phenomenon; that is a rainbow, and feel any God's Majesty; a God who create the universe and its contents.

In the song Pelangi at the first verse, there is also a repeated word pelangi-pelangi alangkah indahmu. Those lyrics show that there is a word repetition. Words are repeated to affirm those words to be more explicit as the main object to point out from this song is pelangi (a rainbow). In addition, the lyrics are very suitable for the children's world so it is very easy for them to memorize and sing the songs.

On the first and second verses, there are similarities of sound at the end of the sentence. The lyrics above are a $u$ - $u$ poet, so that it sounds beautiful to be sung. Sound similarities in both songs' lyrics are as follows.

Pelangi-pelangi alangkah indahmu

Merah kuning hijau di langit yang biru

Here are the sound similarities at the end of the sentence of the third and fourth verses.

Pelukismu agung siapa gerangan

Pelangi pelangi ciptaan Tuhan

The lyrics above are an-an or $a-a$ poetics. The whole song Pelangi has a $u$ $u-a-a$ poetic. The underlined word on the lyrics pelukismu agung siapa gerangan indicates that God is treated like pelukis (the painter). It uses the figure of metaphor. This figure is a metaphorical language as a comparison, but it does not use comparing words, such as bagai, laksana, seperti, etc. The metaphor sees something through other objects, or expresses something as being the same thing, but those are not actually the same (Becker, 1978: 317; and Alternbernd, 1970: 15). 


\section{The song Cicak}

Here is a notation and the lyrics of Cicak which consists of 16 sections bars.

\section{Cicak}

$\mathrm{C}=\mathrm{do}, 2 / 4$

\section{A.T. Mahmud Allegretto}
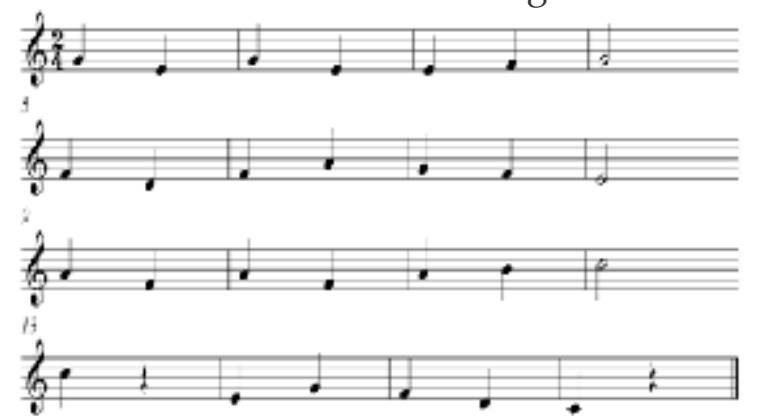

Lyrics:

Cicak cicak di dinding,

Diam diam merayap.

Datang seekor nyamuk,

Hap Lalu ditangkap..

The lyrics describe that the theme of the song is about an animal as one of the God's creations. A.T. Mahmud revealed that cicak (a small lizard) is a fascinating animal. The song lyrics describe about a small lizard which attaches, creeps on the wall, and catches a mosquito. It also shows that all living things have their nature, like mosquitoes that become a prey for small lizards.

The lyrics Hap, lalu ditangkap describe how the small lizard catches a flying animal as a prey. The lyric of 'hap' is a sound to express when the small lizard sticks its long tongue out to catch its prey.

Like the previous two tracks, there is also a word repetition in the first verse in the song cicak that shows an affirmation that cicak is something essential in this song. The characteristics of small lizards when creeping on the wall and how to catch it preys have been the contents of song lyrics that are intended to communicate with children.

\section{Song Analysis from the Aspects of Music Composition}

Song analyses of A.T. Mahmud based on aspects of music composition are as follows.

\section{The song Bintang Kejora}

The song Bintang Kejora uses the scale $\mathrm{F}$ major with a $4 / 4$ bar. It consists of two parts; they are sentence A and sentence $B$. Sentence A consists of eight bars, which are further divided into antecedent and consequent phrases. The antecedent phrases in sentence $A$ lie on the first to the fourth bars, while the consequent phrases sentence A lie on the fifth to eighth bars. The division of sentences in the song can be described as follows.

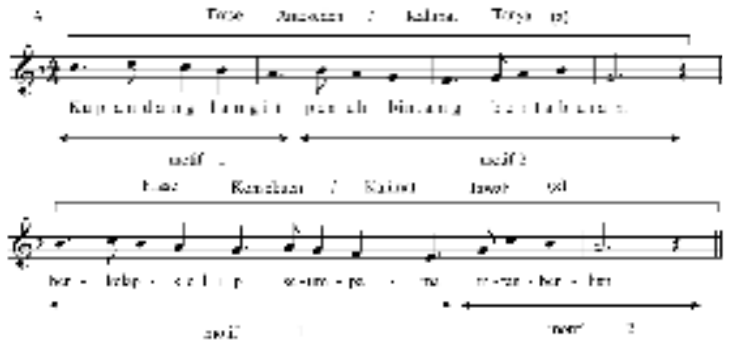

Part B consists of eight bars, which are further divided into antecedent and consequent phrases. The antecedent phrases, sentence B lies on the ninth to twelfth bars, while the consequent phrases, sentence B lies on the thirteenth to sixteenth bars. The division of sentences in the song can be described as follows.

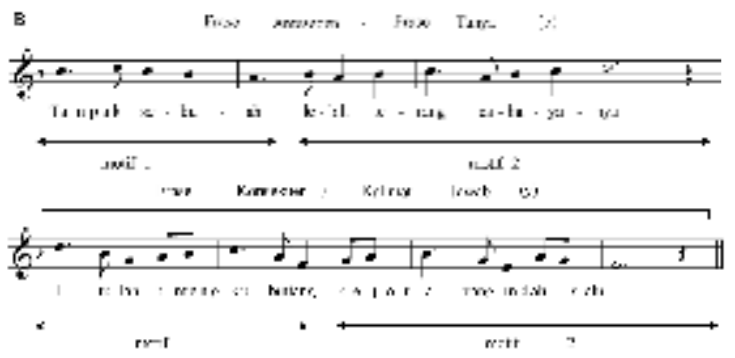

The music notation indicates that Bintang Kejora uses the tone interval between $\mathrm{c} 1$ to $\mathrm{d} 2$. The motion of the melody is stepping and leaping. The form of song with $A$ pattern $(a, x)$ and $B$ pattern $(b, y)$ means that section A consists of two different phrases or sentences that are given the symbol a and $x$. Whereas section $B$ consists of two different phrases or sentences, so it is given the symbol $\mathrm{b}$ and $\mathrm{y}$. 


\section{The song Pelangi}

The song Pelangi uses the scale F major with a $4 / 4$ bar. It is a song that consists of two parts: part A and part B. Part A consists of eight bars, which are further divided into antecedent and consequent phrases. The antecedent phrases lie on the first to the fourth bars, while the consequent phrases lie on the fourth to eight bars. The division of sentences in the song can be described as follows.

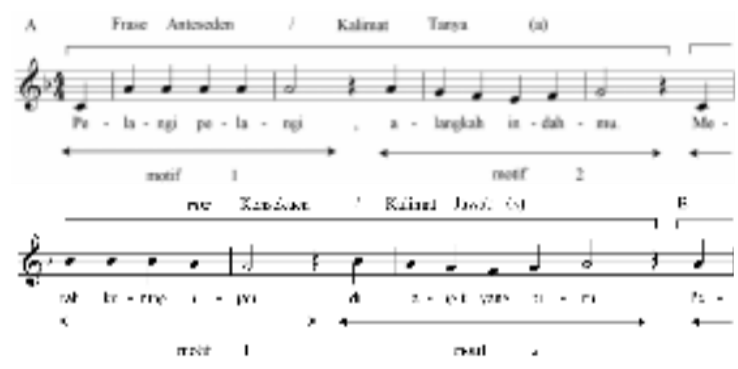

Part B also consists of eight bars that are divided into antecedent and consequent phrases. The antecedent phrases lie on the ninth bar first count to the twelfth bar, while the consequent phrases lie on the twelfth to sixteenth bars. The division of sentences in the song can be described as follows.

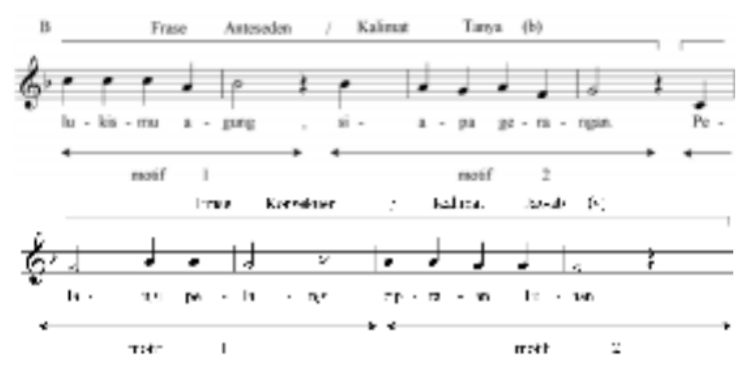

The music notation indicates that $\mathrm{Pe}$ langi uses the tone interval between $\mathrm{c} 1$ to c2. The motion of the melody is stepping and leaping. The form of song with A pattern $(a, x)$ and $B$ pattern $(b, y)$ means that section A consists of two different phrases or sentences that are given the symbol a and $x$. Whereas section $B$ consists of two different phrases or sentences, so it is given the symbol $b$ and $y$.

\section{The Song Cicak}

The song Cicak uses the scale $\mathrm{C}$ ma- jor with a 2/4 bar. It is a song that consists of two parts: part A and part B. Part A consists of eight bars, which are further divided into antecedent and consequent phrases. The antecedent phrases in part A lie on the first to the fourth bars, while the consequent phrases lie on the fifth bar to the eighth bar. The division of sentences in the song can be described as follows.

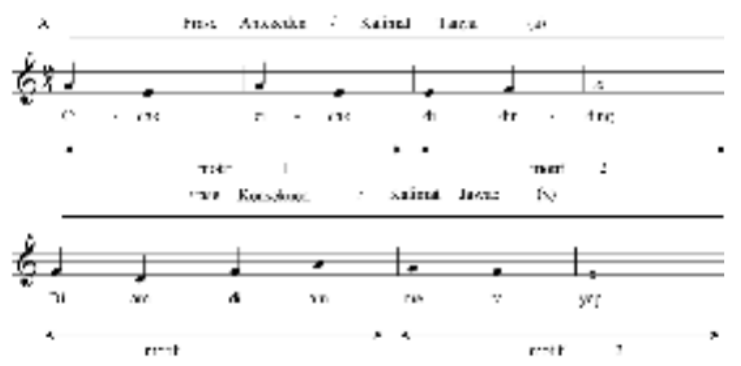

Part B consists of eight bars, which are further divided into antecedent and consequent phrases. The antecedent phrases sentence B lie on the eighth to twelfth bars, while the consequent phrases sentence B lie on the thirteenth to sixteenth bars. The division of sentences in the song can be described as follows.

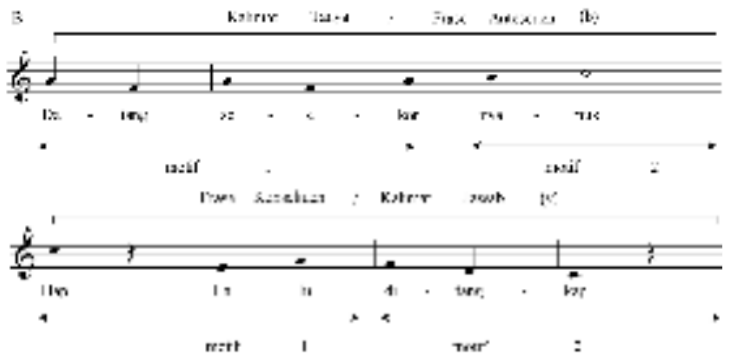

The music notation indicates that Bintang Kejora uses the tone interval between $\mathrm{c} 1$ to $\mathrm{c} 2$. The motion of the melody is stepping and leaping. The form of song with A pattern $(\mathrm{a}, \mathrm{x})$ and $\mathrm{B}$ pattern $(\mathrm{b}, \mathrm{y})$ means that section A consists of two different phrases or sentences that are given the symbol a and $x$. Whereas section $B$ consists of two different phrases or sentences, so it is given the symbol $b$ and $y$.

\section{CONCLUSION}

The songs of A.T. Mahmud mostly has any themes about daily life in ac- 
cordance with the characteristics and the world of children. The songs use the language that corresponds to the children's development, so that it is easily performed and memorized. The forms of the songs by A.T. Mahmud mostly consist of two sections each of which consists of two phrases or sentences. The interval of the tones adjusts to the ability of the child which ranges from c1 to $\mathrm{c} 2$. The motion of a melody uses variations of stepping and leaping with easy tones.

\section{REFERENCES}

Chaer, A. (2003). Linguistik Umum. Jakarta: CV Rineka Cipta

Departemen Pendidikan Nasional. 2008. Kamus Besar Bahasa Indonesia Pusat Bahasa Edisi Keempat. Jakarta: PT Gramedia Pustaka Utama.

Keraf. G. (2007). Diksi dan Gaya Bahasa. Jakarta : PT Gramedia Pustaka Utama.

Intani, E.N. (2012). Developing Modified Indonesian Children Song Lyrics to Teach Vocabulary to Elementary School Third Graders. Englis Education Journal, 2(2), 183-188.

Sinaga, S. S. (2010). Pemanfaatan dan Pengembangan Lagu Anak-anak dalam Pembelajaran Tematik pada Pendidikan Anak Usia Dini. Harmonia: Journal of Arts Research and Edu- cation. 10(1), 30-38.

Sudarmanto, Y.B (ed). (2003). Sebuah Memoar: A.T. Mahmud Meniti Pelangi. Jakarta: PT Gramedia Pustaka Utama.

Suharto, S. (2004). Music and Language: A Stress Analysis of English Song Lyrics. Harmonia: Journal of Arts Research and Education, 5(3), 46-60.

Suharto, S. (2006). Permasalahan Musikal dan Lingual dalam Penerjemahan Lirik Lagu. Harmonia: Journal of Arts Research and Education, 7(2), 133-141.

Suharto, S. (2014). The Equivalence of Translated Songs Lyrics and Their Effects: The Case of Translated Ecclesial Songs. Harmonia: Journal of Arts Re-search and Education. 14(2), 131-139.

Tarigan, H.G. (1986). Pengajaran Semantik. Bandung: Angkasa

Tarigan, H.G \& Guntur, H. (1984). Pengajaran Kosa Kata. Bandung: Angkasa

Nurdiantoro, B. (2005). Sastra Anak: Pengantar Pemahaman Duania Anak. Yogyakarta: Gajah Mada University Press.

Wahyuni, H.F. (2012). Majas dalam Lirik Lagu Album Top Hits Elly Kassim Volume 2. Pendidikan Bahasa dan Sastra Indonesia. 1(1), 364-371.

Thornbury, Scott. (2002). How to Teach Vocabulary. Series Editor: Jermy Harmer. Malaysia: Longman 